\title{
REVIEWS
}

\section{The Academic Form of Science Organization in Ukraine: An Essay on the History (1918-2018)}

The paper highlights the historical course of the main scientific institution in Ukraine as a state institution and shows the interaction of academic institutions with the state in solving issues regarding the scientific, technological and social development of the society.

The traditions of scientific thought in Ukraine began at the Kyiv-Mohyla Academy in the eighteenth century. At the end of the nineteenth and early twentieth centuries, scientific ideas gained noticeable momentum in the development of educational institutions in Kharkiv, Kyiv, Odessa and elsewhere. Engineering thought began to develop here alongside scientific thought. Technical sciences, in combination with natural and social sciences, shaped the foundation of the future Ukrainian Academy of Sciences (UAS) (Paton, 1969, p. 42).

Established in 1918, the academic institution made successful progress in many fields of activity. Some results of the basic and applied researches carried out in the National Academy of Sciences (NAS) of Ukraine were obtained for the first time in the world. The academic form of the organization of science united research institutes of different scientific fields, and consolidated the creative efforts of scientists to solve problems of interdisciplinary nature.

The achievements of the NAS of Ukraine captured the historical and practical interest of researchers, scientists, professors, students of higher technical educational institutions, as well as specialists in certain industries. A number of discoveries were made here. Fundamental and applied researches carried out by the academy's institutions, which were passed to the ministries and departments, provided Ukraine with a leading position in cybernetics, energy, materials science, electrical welding, heavy mechanical engineering, rocket and space industry, biotechnology, and contributed to solving many economic problems (Onyshenko, 2004, p. 19; Paton, 2015, p. 547).

The history of the UAS began on November 27, 1918, when by the Order of Hetman, P. Skoropadsky at the Ministry of Public Education approved the scientific institution with 12 full members. At the General Meeting, 
V. I. Vernadsky was elected as President of the Academy and A.Y. Krymsky as its Permanent Secretary. For almost half a year, the academy received no funding from the authorities. During Denikin's rule in Kyiv, the number of academy's staff decreased twice (from 1,000 to 500). The UAS was one of the most hated citadels of Ukrainian culture for them. After the establishment of Soviet power by the decree of the Revolutionary People's Commissariat of the Ukrainian SSR of July 4, 1919, it was recognized that the UAS was created "as a consequence of the revolutionary activity of the Ukrainian people" (Zvedennja Vseukrajinsjkoji Akademiji nauk..., 1924, pp. 4, 6, 42).

With the establishment of the Soviet regime in 1919, the Government of Ukraine provided the Academy of Sciences with buildings, allotments and entire institutions. A special decree on the inviolability of housing, goods and food, and immunity to the requisites of 14 academicians of the UAS was issued. The transfer of the Government of Ukraine to Kharkiv made the academy provincial and even uninteresting. Researchers' and scientists' salary was insufficient to buy even a pound of bread a day. The academy's staff holding a doctoral degree were forced to leave Kyiv for rural areas to teach and do farmwork. The buildings of the Academy of Sciences were not heated in winter, and its numerous institutions scattered throughout Kyiv had no telephone connections. In 1922, the number of full-time employees of the academy decreased from 606 to 147 , over the following year by another 30 persons. But at the same time, the salary significantly increased for academicians and researchers (Zvedennja Vseukrajinsjkoji Akademiji nauk..., 1924, pp. 4-5; Istorija Akademiji nauk Ukrajiny, 1993, pp. 185, 247248).

One of the peculiarities of the academy's activities since the early 1920s was the adaptation to research in natural and technical sciences. For the first time in the world, the UAS included technical sciences among its fields of activity and included a technical institute in its structure. At that time, the structure of Russian and foreign academies did not yet include technical sciences (Zvedennja Vseukrajinsjkoji Akademiji nauk..., 1924, pp. 160-161; Khrenov, 1954, p. 4).

Several representatives of technical sciences were members of the academy until 1929. That same year the academy consisted of the following scientists: 叉. M. Dinnik, Y. V. Oppokov, Y. O. Paton, G. F. Proskura, M. M. Fedorov, etc. In this period, the largest number of full members since the establishment of the institution was elected to the AUAS (All-Ukrainian Academy of Sciences). Thirty-two full members, including four foreigners, were elected to the three departments of the academy. Due to the absence of personnel in the physics- 
mathematics and social sciences-economics departments, which could carry out the work of the main national economics departments in the near future, it was proposed that branches were organized in Kharkiv (TsDAVO, f. 166, op. 4, cf. 40-41, fol. 3; f. 2, op. 3, ref. 342, fol. 160-163; Materialy..., 1929, pp. 3-7, $13-15,18-28,31-35,36-38]$.

In 1928, the number of national staff of real members of the AUAS was the following: Ukrainians-30, Russians-38, Germans-5. From the Ukrainian SSR there were 45 members, from the Russian Federation - 20, from abroad-9, of whom 4 were Ukrainian scientists: one from Western Ukraine, three from Prague. From 1924 onward, the government funding increased and so did the number of scientific institutions, departments and staff. The range of problems explored in the AUAS was expanding. The development of physics-mathematics and applied sciences became one of the main tasks (TsDAVO, f. 1, op. 6, cf. 149, fol. 142-145; All-Ukrainian Central Executive Committee, 1921).

During the 1920s, by the decision of the Revolutionary People's Commissariat of the Ukrainian SSR, 96 research departments (RDs) were created at higher educational establishments in Kyiv, Odessa, Kharkiv, Katerynoslav and other major cities. They were headed by academicians, who at the same time remained heads of the departments and institutions of the AUAS [TsDAVO, f. 166, op. 2, cf. 43, fol. 1-5; Javorsjkyj, 1926, p. 3-4; Nauka na Ukraine..., 1922, pp. 137138; All-Ukrainian Academy of Sciences, 1929, pp. 78-79].

The work of the RDs in training scientific personnel had several problems. Full members of the departments were employed in other state institutions, where they found better working conditions than in the departments which had no necessary laboratories and offices or equipment for carrying out research work. RDs were not allowed to receive literature from abroad. In 1929, concerns were expressed at the $\mathrm{RD}$ meetings regarding the lack of students interested in studying in graduate school. A number of proposals were made, for example, abandoning the requirement that the candidates should have knowledge of foreign languages. This was considered to be an obstacle for an entry into graduate school for proletarian elements - workers and peasants who did not know or learn foreign languages (TsDAVO, f. R-1628, op. 1, unit collect. 255, fol. 8, 10-11).

In the early 1930s, the development of research branches was replaced with having 59 research institutes (RIs), the prevaling majority of which were created on the basis of the RDs. The main scientific potential of the republic was concentrated in the scientific institutions of the People's Commissariat of 
Education of the Ukrainian SSR. The number of people employed by People's Commissariat of Education institutions was 2,700, including 628 researchers. It was speculated that on the basis of $84 \mathrm{RDs}$, another $35 \mathrm{RIs}$ would be created by merging in the future (Materialy..., 1929, p. 166, op. 9, cp. 1422, pp. 57-61). The research institutes were given the state task to provide scientific support for the purposes of the first five-year plan (1929-1933) on the production of basic goods by branches of industry (TsDAVO, f. R-1628, op. 1, cf. 2, Ark. 13-14).

Against the background of accelerated industrial development, the activities of the AUAS were largely subordinated to increasing the country's military power. In the 1930s, scientific schools in the fields of natural and technical sciences began to be founded at the Academy of Sciences, and close links between science and production were established. The academy was influenced by the decisions made by the leading party. In the second half of the 1930s, 16 members of the academy were arrested, exiled and executed, among them V. Zatonsky, S. Semkovsky, M. Kravchuk, M. Svitlansky, P. Suprunenko, L. Shubnikov, Y. Efremov, A. Krymsky, S. Rudnitsky, and others. A a result, the development of perspective directions of scientific activity became interrupted (Kulchytsky et al., 2000, pp. 198-199).

In the late 1930s, the Academy of Sciences of Ukraine occupied a leading position among almost 350 different scientific and research institutions operating in Ukraine. The government invested increasingly more into its development. While in 1939 the budget of the academy was 21.5 million rubles, in 1940 it expended to 29 million. In 1939, there were 23 institutes in the Academy of Sciences of the Ukrainian SSR, in 1940-their number was 26. In February 1939, 30 full members and 60 corresponding members were elected to the Academy of Sciences of the Ukrainian SSR. The total number of academicians was 66, that of corresponding members was 68 . As a result, many important areas of the academy's work were strengthened. The staff of the academy's researchers increased annually due to doctoral and postgraduate studies (Kuchmarenko, 2003, p. 90).

The scientists of the academy's institutes made a great contribution to ensure defense capability during the war of 1941-1945. In the second half of 1941, the Academy of Sciences was evacuated to the east. It remained the headquarters of Ukrainian science and maintained a qualified part of scientists, and the most valuable scientific equipment. This is where the works on the organization of the Atomic Project started in Kharkiv before the war was carried out. The institutes of the Academy of Sciences were located in Ufa, Nizhny Tagil, Sverdlovsk, Kopeysk, Alma-Ata, where research and development on problems related to the weapons of the Red Army and the creation of new types of defense were established 
and updated. Cooperation with local libraries and museums contributed to the development of both scientific thought in different fields of knowledge and Ukrainian culture (Kulchytsky, 2000, pp. 26, 28; Akademija nauk URSR, 1942; Chernishev, 1944, pp. 3-4).

After the return of the Academy of Sciences from evacuation in March 1944, the institutions' efforts were directed at the development of issues in applied sciences for the restoration of national economy, restoration of working buildings, laboratories and experimental base. Plans for the scientific work at the institutes and laboratories of the Ukranian Academy of Sciences for 1946-1950 reflected a scientific and organizational strategy, the essence of which was to bring science closer to the production, reconstruction and development of the USSR's national economy and, first of all, that of Ukrainian SSR. These plans were combined with those of the USSR Academy of Sciences and the academies of the Union's republics and outlined the research and development of scientific problems in heavy industry; development of railway transport; providing the country with coal, oil, further development of agriculture; improving the supply of food and consumer goods to the population; and enhancing the country's defense capability. The plans highlighted the theoretical problems that required the development of the relevant field of knowledge (Plan naukovo-doslidnykh robit..., 1946, pp. 4-5, 7).

During the 1950s, the international scientific relations of the Academy of Sciences of Ukrainian SSR expanded. This manifested itself in various forms: mutual visits of delegations and individual scientists, a wide exchange of printed scientific publications and scientific and technical information, participation in the work of scientific sessions, conferences and expeditions, including international ones. In 1958, scientists from almost all countries of popular democracy as well as Germany, India, England, Argentina, the USA, France, Japan, Australia, Austria, the Netherlands, Finland, and Thailand visited the Academy of Sciences of the Ukrainian SSR ('Mizhnarodni naukovi...', 1959, p. 68).

Despite the fact that the system of governance impeded the development of certain fields of academic science (prohibition of genetics, inhibition in the development of cybernetics), Ukrainian researchers achieved significant scientific and technical results and gained worldwide recognition in some priority areas. The work of a scientist was held at an advantage compared to other categories of workers. In 1950-1960, the costs for science in Ukraine increased from 284 to 855 million rubles (Onysshenko, 2008, p. 457; Pysarenko, 1989; Stoghnij, 1991, p. 5; Arkhiv Prezydiji..., 1967). 
In 1948, at the peak of a heavy campaign against cybernetics, the Institute of Electrical Engineering of the Academy of Sciences of the Ukrainian SSR received a state order for the creation of an electronic computer (EC) to calculate electricity supply from Kuibyshev to Moscow. At the same time, the intention was to use the machine for military purposes. A team under the lead of Academician S. O. Lebedyev created the first small computer in continental Europe (SEC). In December 1951, the State Commission declared it acceptable for use. The machine was significantly better than the first American lamp computer ENIAC, created in 1946. After the SEC, a big computer (BEC), which was the most productive in Europe and one of the most reliable in the world, was built. It was a perspective direction that allowed the USSR, along with developed countries, to follow the scientific and technological revolution (Ishkov, 1990, pp. 335-338).

In 1957, the Computer Center of the Academy of Sciences of the Ukrainian SSR was established on the basis of the Laboratory of Computational Mathematics and Technology of the Institute of Electrical Engineering of the Academy of Sciences of the Ukrainian SSR and the Institute of Mathematics of the Academy of Sciences of the Ukrainian SSR. In 1962, the Center was transformed into the Institute of Cybernetics of Academy of Sciences of the Ukrainian SSR headed by Academician V. M. Glushkov. Two years later, the construction of the cybernetics center of the Academy of Sciences of the Ukrainian SSR began in Kyiv. It included several institutes, construction, design, research and other structures, united by a general management. The idea of a cybernetics center in the capital of Ukraine was initially supported by neither the USSR Academy of Sciences nor the USSR State Committee for Science and Technology (SCST) (TsDAVO, f. P-2, op. 13, cf. 7536, fol. 55-56).

Scientists of the Institute of Cybernetics of the Ukrainian SSR Academy of Sciences took a leading role in the Soviet Union in the development of computer technology. In 1963, V. M. Glushkov initiated the project of creating in the Soviet Union a single global network USNCC ('United State Network of Computing Centers'). The project of Kyiv's scientists was two years ahead of the American ARPANET project and envisaged the creation of about 200 regional and more than 10,000 local computer centers in the country with prompt processing of received information in Moscow. Glushkov's project, submitted to Moscow in 1964, was waiting for the USSR government's decision until 1970. The USSR Council of Ministers rejected the project without the possibility of financing it. The future has shown that the implementation of Glushkov's project would have been valid and necessary. (Glushkov, 1981, pp. 10-11) 
In the mid-1960s the process of establishing the academy's scientific centers (ASCs) started, including the following: Donetsk's (Donetsk, 1965); Western (Lviv, 1971); Dnepropetrovsk's (Dnepropetrovsk, 1971); Southern (Odessa, 1971); Kharkiv's (Kharkiv, 1971); Northwestern (Kyiv, 1981); and Crimean, which was separated from the Southern National Center (Simferopol, 1997). The cooperation of the Academy of Sciences with the ministries and departments of the Soviet Union and the Republic gradually became a "system of orders" for the implementation of scientific and technical programs. In its institutes, the academy established self-financing design offices and enterprises. These units proved themselves when engineering centers (ECs) and interdisciplinary scientific and technical complexes (ISTCs) first began operating in the Soviet Union. These became an organizational form of creative cooperation of academic institutions with research branch institutes and design institutes and enterprises in solving fundamental and cross-sectoral applied problems (TsDAVO, f. R-2, op. 14, ref. 1162, fol. 28-30).

Even before the early 1960s, a powerful group of young gifted professionals, who were willing and able to work on solving new, advanced scientific and technical tasks of science, was formed at the Academy of Sciences. B. E. Paton's system, which brought together significant numbers and unique knowledge related to basic and applied sciences, laid down the academy's path to success. In the 1960s and 1980s, the institutes of the Academy of Sciences of the Ukrainian SSR became powerful scientific and technical complexes (STCs) that supported a high level of the Soviet economy. By the mid-1980s, several reforms for improvement the management of scientific and technological progress had been undertaken. A clear system of scientific and technical research coordination at the regional level was formed. The main directions of development of basic and applied researches became a reliable foundation which helped to solve complex questions regarding the liquidation of consequences of the Chornobyl catastrophe in 1986 (Onyshhenko, 2004, p. 19).

In March 1986, Ukrainian scientists warned the party-state leadership of the republic about the possibility of catastrophes at Ukrainian nuclear power plants, in Chernobyl in particular. The explosion of the Chernobyl reactor on April 26 the same year polluted the territory of Ukraine, Belarus, Russia, Sweden, Norway, Finland, Lithuania, Germany, Poland, Czech Republic, Switzerland, Austria, Hungary, Romania, Greece, and Bulgaria with radioactive particles. The potential of academic science was involved in neutralizing the discharges of the destroyed reactor. Forty-two institutions of the Academy of Sciences of 
the Ukrainian SSR and about 1,200 of their employees (among them about 550 scientists) participated in the liquidation of the consequences of the accident. The main tasks of scientists, researchers and staff were saving the health of the population and liquidation of the consequences of the accident directly at the Chernobyl nuclear power plant and in the $30 \mathrm{~km}$ zone. In 1986-1990, the institutes of the Academy of Sciences of the Ukrainian SSR developed a national program, which provided training for radiobiologists, radioecologists, spectrometer and dosimeter specialists for work in agriculture, processing and food industry (Chornobylj. 1986-1987 rr..., 2004, pp. 12, 375-376). After the Chernobyl disaster, scientists and researchers of the Ukrainian SSR Academy of Sciences made significant efforts to stop plans of further construction of nuclear facilities in Ukraine.

Since 1987, the academy's institutes focused their efforts on the scientific support of all works carried out within the framework of the Soviet Union's programs, and since 1992, within the programs of the republics. Research was actively carried out at the institutes of the Academy of Sciences of the Ukrainian SSR in the following fields: nuclear research; issues of oncology and radiobiology; hydrobiology; colloidal and water chemistry; metal physics; botany; zoology; geochemistry and mineral physics; physical chemistry; surface chemistry; etc. In 1991, the Department of Radiogeochemistry of the Environment of the Academy of Sciences of the Ukrainian SSR was headed by Academician V. E. Sobotovich, and the Scientific and Engineering Center of Radio Hydroecological Landfill Researches, Academy of Sciences of the Ukrainian SSR (now Radioenvironmental Centre of NAS of Ukraine) was led by corresponding member V. M. Shestopalov (Malynovsjkyj, 2002, pp. 227-228).

With the foundation of the National Center in Ukraine, the development and implementation of regional and comprehensive scientific and technical programs was started for the first time in the Soviet Union and these became an integral part of Union-wide integrated programs. These programs represented a clear form of public administration for the implementation of the national economic tasks in the area of socio-economics, which required the production of equipment that differed from traditional higher technical and economic indicators, such as, for example, labor productivity, expenditure of materials, and consumption of resources. At local or regional levels, scientific and technical programs enabled the relevant authorities to focus the efforts of scientists and producers on the tasks that determined the profile of the region. For example, for the Donbass the program "Coal" was developed and implemented, for the Dnipropetrovsk 
region—the programs "Steel" and "Ore", for Kharkiv— "Energy" and "Tractor T-150” (TsDAVO, f. FR-2, op. 13, ref. 7535, fol. 181).

In 1985, with the direct participation of the Scientific Center of the National Academy of Sciences of the Ukrainian SSR, in all regions of the republic and in Kyiv, scientific and technical programs of national importance were created, such as "Labor"; "AgroComplex" and "Material Contents"; "Transport" in 20 regions and in Kyiv; "Energocomplex" in 16 regions and in Kyiv; "Metal" in 2 regions. In addition, 36 scientific and technical programs of local importance aimed for solving the problems of environmental protection and health care, and improvement of production of mass consumer goods were developed (Arkhiv Prezydiji..., 1986, p. 210).

In total, 68 academic institutions participated in the implementation of comprehensive scientific and technical programs in the mid-1980s. Together with higher education institutions and 130 research branch and design organizations, they performed 1,200 tasks for more than 300 industrial enterprises, which were located in all regions of the republic and belonged to the country's 45 ministries and departments. About half of the tasks were related to the introduction of advanced technologies, new machines, and automatic control systems. Almost 150 tasks were developed to implement the Food Program aimed at improving the efficiency of agricultural production, enhancing of the existing ones and creating new types of agricultural machinery (Nauchnye tcentry..., 1986, p. 32).

In the early 1990 s, the scientific centres covered 1,300 research organizations, 148 universities, research laboratories and academic institutions, and 970 industry sectors. The number of scientists in these centres reached 250,000, including 7,000 doctors and 78,000 candidates of sciences. In 1990, 348,600 people, including 3,200 doctors and 29,300 candidates of science, were engaged in research, development and technological works. The quantitative indicators of science in the academic, university and branch sectors evaluated their strength and separately informed of the achievements of each of them. Most of the scientific centres of National Academy of Sciences of the Ukrainian SSR did not become effective coordinators in the regions, and were unable to unite the efforts of academic institutions, institutes and organizations of different departments to solve the most important problems at the regional and republican level. All the sectors of the scientific and technical complex of Ukraine worked according to the state plan, which excluded competition between them. The sphere of management of the scientific and technical activity by state-party structures proved ineffective. The general organizational and management system of such 
structures excluded the choice of scientific and technical progress (STP) priorities (Marushhak, 1993, pp. 40-41; Buriak \& Pshirkov, 1987, pp. 13-14; Ministry of Statistics of the USSR, 1991, pp. 253).

The interdisciplinary scientific and technical complexes (ISTCs) were the highest form of research organizations within the scientific centres. They significantly influenced the effectiveness of the introduction of new developments in the national economy of several sectors of Ukraine and other Soviet republics. Organizational deficiencies caused by the centralized management and limitation of material, financial and other resources impeded their development. In 1989, the state's order for updating the material and technical research base of the academic institutions of the republic was underfulfilled more than in previous years. The Academy of Sciences of the USSR, as a higher-status authority, limited the financing of the scientific activity of the Academy of Sciences of the Ukrainian SSR. The USSR Academy of Sciences allocated several times more money to its capital building, scientific equipment and other needs than for the Academy of Sciences of Ukraine. That is why it lagged 7-8 years behind the Western countries in the level of equipment and technical support (Marushhak, 1993, pp. 41-42; Kyslyj, 1993, pp. 9-10; Pravda Ukrainy, 1990).

The academic form of organizing Ukraine's science made a significant contribution to the nuclear, missile, and space industries. After 1970, work on the creation of space-based weapons under the Star Wars program began. Scientists participated in the implementation of "Uranium" and "Aerospace" state programmes. Ukraine is among the seven countries in the world that have developed management of fusion reaction. In 1990, 20\% of research centers: research institutes, design and engineering institutions, and 30\% of the republic's machine-building industry worked on the military-industrial complex of the Soviet Union (Maklin \& Palm’jeri, 1993, pp. 65; Kogan \& Sofronii, 2008, pp. 42-43).

In 1990, the science of Ukraine significantly influenced the level of scientific and technical development of enterprises in metallurgical, coal, chemical, machinebuilding, light, food and other industries, the products of which characterized not only the national economic complex of the republic, but also the Union. In the USSR, Ukraine occupied only $2.7 \%$ of its territory. It produced $20 \%$ of the country's industrial output, including $33 \%$ of steel, $50 \%$ of vehicles: locomotives, ships and planes; and much of production were made on the basis of high technology. The national economy of the republic produced 5\% of the world's production (Maklin \& Palm'jeri, 1993, p. 65). 
During the 1980s, the institutes of the Academy of Sciences significantly expanded cooperation with the scientific and industrial centers of the People's Republic of Bulgaria, Hungarian People's Republic, Poland, the Socialist Republic of Romania, the Czechoslovak Socialist Republic, the Republic of Cuba, Austria, France, Germany, Finland, and other countries. In 1987, 32 institutes of the Academy of Sciences were involved in the implementation of the Integrated Program of Scientific and Technological Progress of the Mutual Economic Assistance Council (MEAC) countries until 2000. Thirty-two contracts were concluded, and four contracts were signed with foreign partners. Joint SovietBulgarian laboratories for powder metallurgy and welding robotics began to operate, and an international competition for creating a software interface was announced. The corresponding task of the Comprehensive Program was included in the State Plan of Social and Economic Development of the USSR for 1987. The scientific management of the direction "New materials and technologies in production and processing" relied on the Academy of Sciences of the Ukrainian SSR. The same year, in 1987, the first results were obtained. In particular, in cooperation with Bulgaria and Czechoslovakia, the plant of electron beam sputtering and evaporation was created. The Karl-Zeiss Company (German Democratic Republic) successfully used new powder cathode elements from lanthanum hexaboride, developed by specialists of the Academy of Science (Arkhiv Prezydiji..., 1998, p. 8).

During the years of independence of Ukraine, science has not become a state priority. It has been funded on a residual basis. Due to the war in eastern Ukraine, 11 of the 12 scientific institutions of the Donetsk region were evacuated from the war zone. Ten establishments of the Academy of Sciences are closed. Nine scientific institutions remained in Crimea. With their loss, in particular, O. O. Kovalevsky Institute of Biology of the Southern Seas and Marine Hydrophysical Institute, Ukrainian state has lost the opportunity to study the processes taking place in the world ocean, which are of great importance for the country's economy and defense (Bjesov \& Zvonkova, 2014, p. 43).

The atmosphere of hostility towards the NAS of Ukraine has increased especially since 2000. The pages of the newspapers Ukrainian Truth, The Mirror of the Week, The Voice of Ukraine, 2000 and a number of others ones have clearly shown the "attention" of individual authors in terms the future of the Academy of NAS of Ukraine, considering it to be an unnecessary state structure. The reaction of B. E. Paton on the attacks of those who intended to destroy it was as follows: 
The academic form of science organization, especially the fundamental one, is fully justified. Opposition to its so-called Western model, which is actively presented from time to time on the pages of newspapers and journals, is caused first of all by the incompetence of certain publicists and their superficial knowledge of the same foreign experience. They considered Academy of Sciences as a kind of "Soviet invention", the origination of a totalitarian system. In fact, the creation of academies was caused first of all by the growth and complexity of science itself, the necessity to deal with it professionally and collectively, in the structure of powerful research teams. That is why Leibniz advocated the liberation of the scientist from the need to make money by lecturing, in order to give him the opportunity to fully devote himself to science. This was the main reason that prompted him to initiate the creation of academies in Germany and in Russia [...] Academic form of organization of science, which combines the institutions of various scientific fields as no other, allows to consolidate the efforts of scientists to solve complex problems of interdisciplinary nature. (Paton, 2015, p. 547)

\section{Galyna Zvonkova, PhD}

State Institution Institute for Scientific and Technological Potential and Science History Studies, AHEM. Dobrov NAS of Ukraine

\section{Vira Gamaliia, PhD}

Department of Philosophy and History of Science and Technology, State University of Infrastructure and Technology, Ukraine

\section{References}

Akademija nauk URSR (1942), [Academy of Sciences of the Ukrainian SSR], Ufa: "Okt. natysk".

All-Ukrainian Academy of Sciences (1929), Visti VUAN [News of AUAS], no. 3/4.

All-Ukrainian Central Executive Committee (1921), Visti VUCVKVisti Vseukrayins'koho Tsentral'noho Vykonavchoho Komitetu [News of the All-Ukrainian Central Executive Committee], ch. 132.

Arkhiv Prezydiji... (1967), Arkhiv Prezydiji NAN Ukrajiny: Otchet o dejateljnosty Akademyy nauk Ukraynskoj SSR v 1966 ghodu [Archive of the Presidium of the NAS of Ukraine: Report on the activities of the Academies of Sciences of the Ukrainian SSR in 1966], Kyiv: Nauk. dumka.

Arkhiv Prezydiji... (1986), Arkhiv Prezydiji NAN Ukrajiny: Otchet o dejateljnosty Akademyy nauk Ukraynskoj SSR v 1985 ghodu [Archive of the Presidium of the NAS 
of Ukraine: Report on the activities of the Academies of Sciences of the Ukrainian SSR in 1985], Kyiv: Nauk. dumka.

Arkhiv Prezydiji... (1988), Arkhiv Prezydiji NAN Ukrajiny: Otchet o dejateljnosty Akademyy nauk Ukraynskoj SSR v 1987 ghodu. V dvukh chastjakh [Archive of the Presidium of the NAS of Ukraine: Report on the activities of the Academy of Sciences of the Ukrainian SSR in 1987. In two parts], Part 1, Kyiv: Naukova dumka.

Bjesov, L. M. \& Zvonkova, Gh. L. (2014), 'Akademichna nauka Krymu' [Academic Science in Crimea], in Materialy 13-ji nauk. konf. "Aktualjni pytannja istoriji nauky i tekhniky Krymu" 8 zhovtnja 2014 roku, m. Korostenj, Kyjiv [Materials of the 13th scientific conference 'Relevant issues in the history of science and technology in Crimea', October 8, 2014, Korosten, Kyiv], pp. 40-43.

Buriak, A. A. \& Pshirkov, N. S. (1987), 'Regionalnaia akademicheskaia nauka i uskorenie nauchno-tekhnicheskogo progressa' [Regional academic science and the acceleration of scientific and technological progress], Vestnik Akademii nauk SSSR, no. 9, pp. 14-23.

Chernishev, B. I., ed. (1944), Dopovidi viddilu fizyko-khimichnykh i matematychnykh nauk [ Reports of the departments of physical, chemical and mathematical sciences], Kuibyshev: Typ. ym. Mjaghy tresta "Polyghrafknygha” Oghyza RSFSR.

Chornobylj. 1986-1987 rr... (2004), Chornobylj. 1986-1987 rr. Dokumenty i spoghady. Rolj AN Ukrajiny u podolanni naslidkiv katastrofy [Chernobyl. 1986-1987. Documents and memoirs. The role of the Academy of Sciences of Ukraine in overcoming the consequences of the catastrophe], Kyiv: Akademperiodyka.

Glushkov, V. M. \& Valakh, V. Ia. (1981), Chto takoe OGAS? [What is OGAS?] Moscow: Nauka.

Ishkov, M. N., ed. (1990), Ot makhin do robotov (v 2-kh knigakh) [From machines to robots (in 2 vols.)], vol. 2, Ocherki o znamenitykh izobretateliakh, otryvki iz dokumentov, nauchnykh statei, vospominanii, teksty patentov 2-kh knigakh [Essays on famous inventors, excerpts from documents, scientific articles, memoirs, patents in 2 vols.], Moscow: Sovremennik.

Istorija Akademiji nauk Ukrajiny... (1993), Istorija Akademiji nauk Ukrajiny: 1918-1923. Dokumenty i materialy [History of the Ukrainian Academy of Sciences: 1918-1923. Documents and materials], Kyiv: Naukova dumka.

Javorsjkyj, M. (1926), 'Najblyzhchi zavdannja orghanizaciji naukovoji praci na Ukrajini' [The primary tasks in the organization of scientific work in Ukraine], in Nauka na Ukrajini. Bjuletenj Ukrnauky [Science in Ukraine: Bulletin of Ukrainian Science], Kyiv: Derzh. vyd-vo Ukrajiny, pp. 3-12.

Khrenov, K. K. (1954), 'Vklad ukrainskikh uchenykh v razvitie sovetskoi nauki i tekhniki' [The contribution of Ukrainian scientists to the development of Soviet science and technology], Izvestiia Akademii nauk SSSR [Proceedings of the Academy of Sciences of the USSR], no. 1, pp. 3-13. 
Kogan, V. S. \& Sofronii, V. V. (2008), Sotrudniki UFTI-uchastniki Velikoi Otechestvennoi voiny [UFTI employees_-participants of the Great Patriotic War], Kharkiv: Timchenko.

Kuchmarenko, V. A.; et al. (2003), Istorija Nacionaljnoji akademiji nauk Ukrajiny. 1938-1941: Dokumenty $i$ materialy [History of the National Academy of Sciences of Ukraine. 1938-1941: Documents and materials], Kyiv.

Kulchytsky, S. V.; et al. (2000), Istorija Nacionaljnoji Akademiji nauk Ukrajiny $v$ suspiljno-politychnomu konteksti. 1918-1998 [History of the National Academy of Sciences of Ukraine in the socio-political context. 1918-1998], Kyiv.

Kyslyj, P. (1993), 'Lavry nauky i terny reorghanizaciji' [Laurels of science and thorns of reorganization], Viche, no. 4, pp. 3-17.

Maklin, M. B. \& Palm'jeri, D. A. (1993), 'Perekhid do rynkovoji systemy cherez konversiju oboronnoji systemy' [The transition to a market system through the conversion of the defense system], Politychna dumka, no. 1, pp. 65-68.

Malynovsjkyj, B. M. (2002), Borys Paton - pracja na vse zhyttja [Borys Paton-It's a life-long work], Kyiv: Akademperiodyka.

Marushhak, V. (1993), 'Meta-myr, dobrobut, vzajemorozuminnja: naukovotekhnichni aspekty ekonomichnoji vzajemozalezhnosti u suchasnomu sviti' [Purpose - peace, prosperity, mutual understanding: scientific and technical aspects of economic interdependence in the modern world], Polityka i chas, no. 10, pp. 40-42.

Materialy... (1929), Materialy do obrannja novykh akademikiv VUAN. Kharakterystyky kandydativ ta akademikiv VUAN, podanykh zdoruchennja osoblyvykh komisij [Materials for the election of new academicians of AUAS. Characteristics of candidates and academicians of AUAS, submitted on behalf of special commissions], Kyiv: Derzh. Trest "Kyiv-Druk".

Ministry of Statistics of the USSR (1991), Narodne ghospodarstvo Ukrajinsjkoji RSR $u$ 1990 roci: Stat. shhorichnyk [The national economy of the Ukrainian SSR in 1990: Stat. yearbook], Kyiv: Tekhnika.

'Mizhnarodni naukovi...' (1959), 'Mizhnarodni naukovi zv'jazky AN URSR u 1958 r. (oghljad)' [International Scientific Communications Academy of Sciences of the USSR in 1958 (review)], in Visnyk Akademiji nauk Ukrajinsjkoji RSR [Bulletin of the Academy of Sciences of the Ukrainian SSR], no. 5, pp. 68-73.

Nauchnye tcentry... (1986), Nauchnye tcentry Akademii nauk Ukrainskoi SSR (opyt $i$ prspektivy) [Scientific Center of the Academy of Sciences of the Ukrainian SSR (experience and prospects)], Kyiv: Nauk. dumka.

Nauka na Ukraine... (1922), Nauka na Ukraine. Organ nauchnogo komiteta Ukrglavprofobra [Science of Ukraine. Body of the scientific committee of Ukrglavprofobr], no. 1.

Onyshhenko, O. S. (2004), 'Istorija formuvannja vitchyznjanogho kompleksu fundamentaljnoji nauky' [History of the formation of the Vitchyznyanogo complex of fundamental science], in Naukovi dopovidi: 85 rokiv Nacionaljnoji Akademiji nauk Ukrajiny [Scientific reports: 85 years of the National Academy of Sciences of 
Ukraine], no. 1, Kyiv: Visnyk Nacionaljnoji Akademiji nauk Ukrajiny, pp. 15-22.

Onyshhenko, O. S. et al., eds. (2008), Istorija Nacionaljnoji akademiji nauk Ukrajiny. 1946-1950 [History of the National Academy of Sciences of Ukraine. 1946-1950], Part 1, Kyiv: NBUV.

Paton, B. E. (1969), 'Vidkryttja i problemy' [Discoveries and problems], in B. E. Paton (ed.) Nauka i kuljtura, Ukrajina [Science and culture, Ukraine], Kyiv: Vyd-vo t-va "Znannja” ta Akademiji nauk URSR, pp. 42-49.

Paton, B. E. (2015), 'Materialy dlia tekhnologicheskikh proryvov' [Materials on technological breakthroughs] in V. I. Onoprienko (ed.) Legendy sovetskoi nauki: Ocherki ob uchenykh [The legends of Soviet Science: essays on scientists], Chisinau: Lambert Academic Publishing.

Plan naukovo-doslidnykh robit... (1946), Plan naukovo-doslidnykh robit Akademiji nauk Ukrajinsjkoji Radjansjkoji Socialistychnoji Respubliky na 1946-1950 rr: Proekt [Plan of research work of the Academy of Sciences of the Ukrainian Soviet Socialist Republic for 1946-1950: Programme], Kyiv: Vyd-vo AN URSR.

Pravda Ukrainy (1990), 'Ekonomika respubliki: itogi minuvshego goda' [The economy of the republic: results of the past year], 2 February.

Pysarenko, Gh. S. (1989), Zhyznj v nauke: Gh.S. Pysarenko [Life in science: G. S. Pysarenko], Kyiv: Nauk. dumka.

Stoghnij, B. S. (1991), 'Misce i rolj akademichnoji nauky u suchasnykh umovakh' [The place and role of academic science in modern conditions], Visnyk Akademiji nauk Ukrajiny, no. 10, pp. 3-8.

TsDAVO, Fond Kharkivsjkogho tekhnologhichnogho instytutu [Fond of Kharkiv Institute of Technology], Centraljnyj Derzhavnyj arkhiv vyshhykh orghaniv vlady i upravlinnja Ukrajiny: fond Kharkivsjkogho tekhnologhichnogho instytutu, f. R-1628, op. 1, cf. 2, Ark. 13-14, Central State Archives of Supreme Bodies of Power and Government of Ukraine, Kyiv.

TsDAVO, Fond Narodnogho Komisariatu Osvity [People's Commissariat of Education], Tsentraljnyj Derzhavnyj arkhiv vyshhykh orghaniv vlady i upravlinnja Ukrajiny, f. 166, op. 4, cf. 40-41, fol. 3; f. 2, op. 3, ref. 342, fol. 160-163, Central State Archives of Supreme Bodies of Power and Government of Ukraine, Kyiv.

TsDAVO, Fond Rady Ministriv Ukrajinsjkoji RSR [Fond of Council of Ministers of the Ukrainian SSR], Derzhavnyj arkhiv vyshhykh orghaniv vlady i upravlinnja Ukrajiny, f. P-2, op. 13, cf. 7536, fol. 55-56, Central State Archives of Supreme Bodies of Power and Government of Ukraine, Kyiv.

Zvedennja Vseukrajinsjkoji Akademiji nauk... (1924), Zvedennja Vseukrajinsjkoji Akademiji nauk u Kyjevi za 1923 rik (z naghody p’jatyrichnogho zasnuvannja Akademiji. 1918-1923) [Building of the All-Ukrainian Academy of Sciences in Kyiv in 1923 (on the occasion of the five-year founding of the Academy. 1918-1923)], Kyiv: Druk. Ukrajinsjkoji Akademiji nauk. 